\title{
The Performance Evaluation of Endotoxin Retentive Filters in Haemodialysis
}

\author{
Tetsuya Kashiwagi ${ }^{1}$, Kazuto Sato ${ }^{2}$, Seiko Kawakami², Masayoshi Kiyomoto ${ }^{2}$, \\ Hiroyuki Takei', Tatsuya Suzuki³, Hirokazu Genei ${ }^{3}$, Hiroaki Nakata ${ }^{3}$, \\ Yasuhiko Iino ${ }^{1}$ and Yasuo Katayama ${ }^{1}$ \\ ${ }^{1}$ Department of Neurological, Nephrological and Rheumatological Science, Graduate School of Medicine, Nippon Medical School \\ ${ }^{2}$ Adachi Iriya Toneri Clinic, Tokyo \\ ${ }^{3}$ Kitasenju East Kidney Clinic, Tokyo
}

\begin{abstract}
Background: Hemodialysis is a method for removing uremic toxins and water directly from the blood into a dialysis fluid through an artificial semipermeable membrane called a dialyzer. The ability of the dialyzer to remove uremic toxins has steadily improved, but the likelihood has also increased that bioactive substances, such as bacterial endotoxin (ET) fragments, can be transferred from the dialysis fluid into the patient's blood through the phenomena of back-diffusion and back-filtration in the dialyzer. Therefore, further efforts to improve the quality of water are required. In 2008, the Committee of Scientific Academy of the Japanese Society for Dialysis Therapy presented its new recommendations for the quality standards of dialysis fluid, but achieving and maintaining these standard values would seem difficult without installing an ET-retentive filter (ETRF). In the present study, we evaluated whether the standards for ultrapure dialysis fluid of the Japanese Society for Dialysis Therapy can be achieved and maintained by installing 3 types of ETRF for a period of 12 months.

Methods: To evaluate the quality of dialysis fluid, ET values were measured with nephelometry, and viable cell counts were determined with the membrane filter method. Changes in the basic performance of the ETRFs were evaluated by measuring their water permeability, ET-retentive capacity, and hollow-fiber membrane intensity. Moreover, the hollow-fiber membrane surfaces of the ETRFs were observed with scanning electron microscopy, and the elements of the adherent substances were identified by means of energy dispersive X-ray spectrometry.

Results: The ET concentrations were less than the limit of detection during the evaluation period for samples obtained at post-ETRF sites. The viable cell counts for pre-ETRF sites were approximately 10 colony-forming units $/ \mathrm{mL}$. However, colonies had not formed in samples obtained from the post-ETRF sites. The substances adhering to hollow fibers included the silicon from the dialysate powder, the iron from the fluid path, and the elements derived from stainless steel. Scanning electron microscopy of the ETRF hollow fibers showed no substances except the hollow fibers and the elements derived from the dialysis fluid.

Conclusion: Installation of an ETRF is useful for achieving and maintaining the quality standards for ultrapure dialysis fluid and for preventing the entry into the blood of ETs, viable cells, and such substances as silicon and metals.
\end{abstract}

(J Nippon Med Sch 2011; 78: 214-223)

Key words: hemodialysis, dialyzer, endotoxin retentive filter, water quality management

Correspondence to Tetsuya Kashiwagi, MD, PhD, Division of Neurology, Nephrology, and Rheumatology, Department of Internal Medicine, Nippon Medical School, 1-1-5 Sendagi, Bunkyo-ku, Tokyo 113-8603, Japan E-mail: tk@nms.ac.jp Journal Website (http://www.nms.ac.jp/jnms/) 


\section{Introduction}

Hemodialysis is a method for removing uremic toxins and water directly from the blood into a dialysis fluid through an artificial semipermeable membrane called a dialyzer by circulating the blood outside the body at a rate of 150 to $250 \mathrm{~mL} /$ minute. To remove a large quantity of uremic toxins, a large volume of dialysis fluid $(0.5 \mathrm{~L} /$ minute $\times 60$ minutes $\times$ 4 hours $=120 \mathrm{~L}$ ) is used for a single dialysis treatment; therefore, the dialysis fluid is usually not sterilized. Moreover, because many different processes are needed to produce the dialysis fluid, the risk of bacterial contamination is high. Although the ability of dialyzers to remove uremic toxins has steadily improved, the likelihood has increased that bioactive substances, such as bacterial endotoxin (ET) fragments, are transferred from the dialysis fluid into the patient's blood through the phenomena of back-diffusion and back-filtration in the dialyzer ${ }^{1-5}$. Therefore, further efforts are required to improve the quality of water.

Although acute reactions, such as pyrexia, hypotension, and shock, to large quantities of ETs have long been recognized, chronic reactions to ETs are less well understood ${ }^{6}$. Recent studies have confirmed that several kilodaltons of bacterial ET fragments can be transferred into the patient's blood during dialysis ${ }^{7-11}$. Furthermore, even an extremely low concentration of ETs in dialysis fluid $(0.00231$ $\mathrm{EU} / \mathrm{mL}$ ) can induce the production of cytokines ${ }^{12,13}$. Repetitive, long-term exposure to such extremely low ET concentrations can also induce various dialysis-related complications ${ }^{6}$.

Several Japanese scientific academies, which have proposed strict ET standards for the management of water quality, have added standards for viable cell counts to their recommendations in line with the standards of the International Organization for Standardization, which are now under review and emphasize viable cell counts ${ }^{14,15}$. In 2008, the Committee of Scientific Academy of the Japanese Society for Dialysis Therapy presented its new recommendations for the quality of dialysis water. The new recommendations are the first to specify viable cell counts and ET values for standard dialysis fluid $(<100$ colony-forming units [CFU] $/ \mathrm{mL}$ and $<0.050 \mathrm{EU} / \mathrm{mL}$, respectively) and ultrapure dialysis fluid $(<0.1 \mathrm{CFU} / \mathrm{mL}$ and $<0.001 \mathrm{EU} / \mathrm{mL}$, respectively $)^{14}$. Therefore, to achieve and stably maintain the water quality standards of the Japanese Society for Dialysis Therapy, installing a particulate-removing filter (i.e., an ET-retentive filter [ETRF]) is more important than ever. In the present study, we evaluated whether the quality standards for ultrapure dialysis fluid can be achieved and maintained by installing several types of ETRF.

\section{Subjects and Methods}

\section{Subjects}

The evaluation was performed in 2 facilities, our corporate member facilities $\mathrm{A}$ and $\mathrm{B}$. The ETRFs used were the CF-609N (Nipro Corp., Osaka), EF-02 (Nikkiso Co., Ltd., Tokyo), and TET-1.0 (Toray Industries, Inc., Tokyo). Two of the 3 ETRFs in each facility were newly installed and then evaluated for 12 months: 8 CF-609N ETRFs and 8 EF-02 ETRFs were used in facility A, and $8 \mathrm{CF}-609 \mathrm{~N}$ ETRFs and 6 TET-1.0 ETRFs were used in facility B. Facility A has introduced a console dialysis unit (DCS-27, Nikkiso Co., Ltd.) that includes an EF-02 ETRF as standard equipment; therefore, the ET-02 ETRF is the only ETRF used under normal clinical conditions in this facility. On the other hand, facility B uses an older console dialysis unit (TR-2000MV, Toray Industries, Inc.) that does not have an ETRF-flushing function. For this reason, the CF-609N ETRF, the instructions for which periodic flushing is not clearly demanded, has been adopted in facility B. For this study, the CF-609N was also adopted by facility A, where periodic flushing was performed, so that differences between the ETRFs could be evaluated. The timing of ETRF replacement (the manufacturers' recommended duration of use) is generally 3 to 6 months $^{16}$, and no significant difference in the performance of each ETRF is indicated over this period; therefore, we concluded that that long-term use could be compared without bias. The duration of ETRF use varies with such conditions in the facilities as the water quality before 
Table 1 The evaluated ETRFs specification ${ }^{5}$ (modified in part)

\begin{tabular}{lccc}
\hline \multicolumn{1}{c}{ Product name } & CF-609N & EF-02 & TET-1.0 \\
\hline Membrane material & $\begin{array}{c}\text { Hydrophobic } \\
\text { Polyethersulfone }\end{array}$ & $\begin{array}{c}\text { Hydrophobic Polyester } \\
\text { polymer alloy }\end{array}$ & Hydrophilic Polysulfone \\
\hline Hollow fiber inner diameter $(\mu \mathrm{m})$ & 500 & 210 & 200 \\
\hline Membrane thickness $(\mu \mathrm{m})$ & 150 & 30 & 40 \\
\hline Effective area $\left(\mathrm{m}^{2}\right)$ & 0.6 & 1.2 & 1.0 \\
\hline Molecular weight cut off & 6,000 & 30,000 & 30,000 \\
\hline
\end{tabular}

\section{Facility A}

Flushing* for both EF-02 and CF-609N

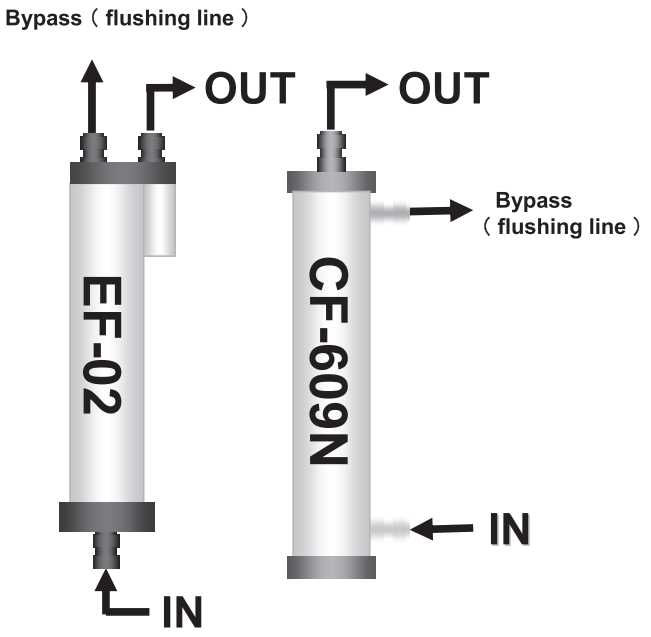

\section{Facility B}

Flushing only for TET-1.0

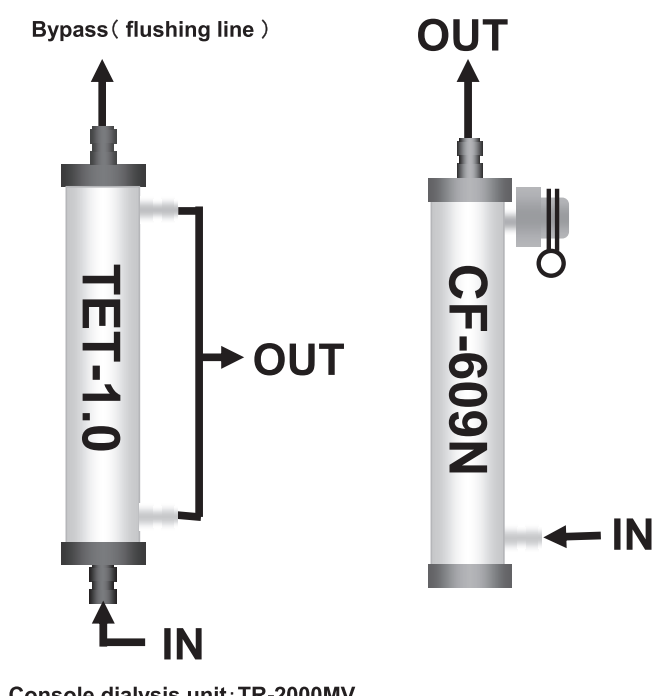

* Flushing: one of the washing methods of a console dialysis unit mainly for the purpose of ETRF maintenance preventing the ETRF from clogging by switching the water passage in the ETRF. The flushing function is not regularly equipped in the console dialysis unit TR-200MV in the facility B. The instructions of TET-1.0 ETRF recommend periodic flushing implementation. Therefore, for the console dialysis unit which TET-1.0 ETRF was installed, the flushing mechanism was equipped as an option.

Fig. 1 The methods of the ETRFs installation

ETRF treatment and the washing/disinfection method. Long-term use of the ETRF is considered reasonable if the percolation performance and trapping performance for ETs and microbes are properly maintained ${ }^{16,17}$ and if the timing of replacement is decided by each facility. In the 2 facilities for this study, periodic microbiological monitoring was performed every month by determining ET activities and viable cell counts in laboratory cultures for the ETRF routinely used in the facility; because the ET activity has been less than the limit of detection and the viable cell count has been zero for 12 months, 1 year was set as the interval for ETRF replacement. However, neither facility had data concerning the safety of long-term use of the ETRF that was not routinely used in the facility and was evaluated in this study. Therefore, to ensure safety the second ETRF was installed after 6 months of the study period because of the possibility of leakage and other problems downstream of the evaluated ETRF. The patients were informed of this installation schedule, and their acknowledgement was confirmed.

The specifications for evaluating the ETRFs are shown in Table $\mathbf{1}^{5}$.

\section{Methods}

The method for installing ETRFs is shown in 


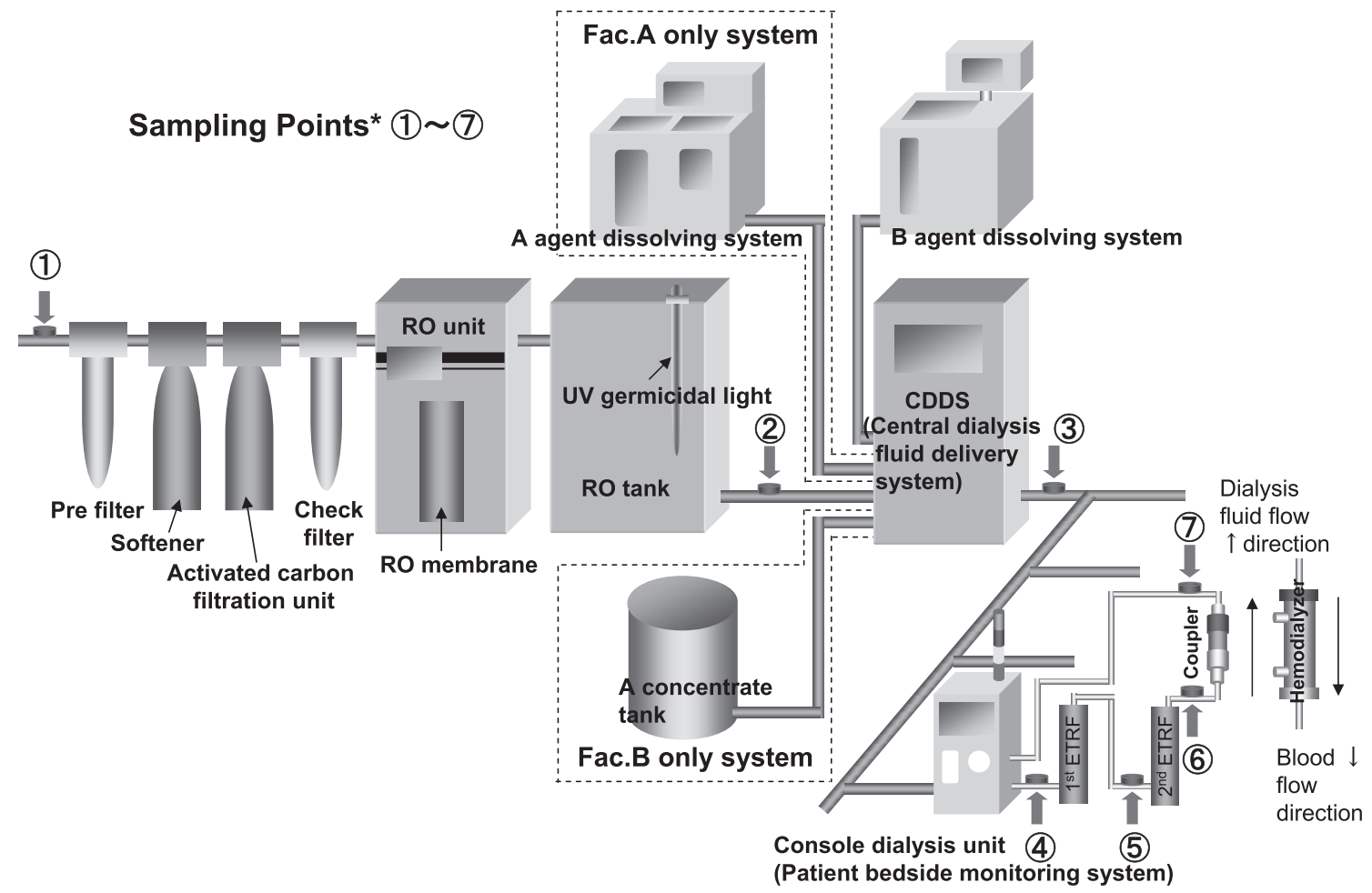

* Sampling points: (1) raw water (tap water), (2) RO water, (3) CDDS exit site, (4) the ETRF entry site, (5) the evaluated ETRF exit site (after passing the first ETRF), (6) the coupler adjacent site (after passing the second ETRF), (7) the coupler exit site

Fig. 2 The flow diagram of water treatment and dialysis making/supplying system

Figure $\mathbf{1}^{18}$. The inside-out filtration method was used to install the EF-02 and TET-1.0 ETRFs and the outside-in filtration method was used to install the CF-609N following the respective instruction manuals. The systems for water treatment and dialysis fluid production are shown in Figure 2, and the role of each site is shown in Table 2. The CF$609 \mathrm{~N}$ ETRF in facility B was used without being flushed because of the specifications of the console in which it was installed. The other ETRFs were flushed by shifting the fluid passing between the filtrate side and the drainage side during the rinsingdisinfection process and the fluid exchange process of the central dialysis fluid delivery system (CDDS). Additionally, after the first 6 months of the study period, the CF-609N ETRF was installed as a second ETRF downstream of the evaluated ETRF to ensure safety. For the evaluation of dialysis fluid quality, viable cell counts and ET concentrations were measured at each point of use. Samples were obtained at 7 sites in order from upstream to downstream: 1) raw water, 2) reverse osmosis (RO) water, 3) the CDDS exit site, 4) the ETRF entry site,
5) the evaluated ETRF exit site (after passing the first ETRF), 6) the coupler adjacent site (after passing the second ETRF), and 7) the coupler exit site. The samples were obtained before the start of dialysis treatment from the terminal site in a retrograde fashion (from downstream to upstream) after the dialysis fluid had passed for more than 5 minutes. Meanwhile, samples were obtained at the coupler exit site after the load to the coupler under normal conditions was simulated by applying a rotational load to the coupler with a bypassconnector connection.

The ET concentrations were measured with nephelometry using the Limulus test (Toxinometer MT-358; Wako Pure Chemical Industries, Ltd., Osaka), and viable cell counts were determined with the membrane filter method (37-mm quality monitor and M-TGE broth; Pall Corp., Port Washington, NY, USA) after the sample had been incubated for 14 days at room temperature $\left(25^{\circ} \mathrm{C} \pm 1{ }^{\circ} \mathrm{C}\right)$. The filtrate volume was $10 \mathrm{~mL}$ for samples obtained at preETRF sites. For post-ETRF sites, $10 \mathrm{~mL}$ was filtered for the first 3 months and $100 \mathrm{~mL}$ was filtered after 
Table 2 The roles of each part of water treatment and dialysis fluid making/supplying system

\begin{tabular}{|c|c|}
\hline $\begin{array}{l}\text { Pre Filter } \\
\text { (Primary Filter) }\end{array}$ & $\begin{array}{l}\text { Pore size: } 10 \text { to } 50 \mu \mathrm{m} \text {. Shape: Spool or laminated type filter. Used to remove rough } \\
\text { particle, such as iron rust and sand in raw water. Usually installed prior to water- } \\
\text { softening system and activated-carbon system. }\end{array}$ \\
\hline $\begin{array}{l}\text { Water-softening } \\
\text { System (Softener) }\end{array}$ & $\begin{array}{l}\text { The calcium ion and magnesium ion in raw water serve as insoluble deposit matter on } \\
\text { the membrane surface of the RO concentrate side and deteriorate RO membrane, and } \\
\text { then cause reduction of percolation performance. Installed to remove those hard elements } \\
\text { as a pretreatment system of RO unit. }\end{array}$ \\
\hline $\begin{array}{l}\text { Activated-Carbon } \\
\text { System }\end{array}$ & $\begin{array}{l}\text { Prevent deterioration of polyamide series } \mathrm{RO} \text { membrane which is vulnerable to Chlorine } \\
\text { Utilize the absorption capacity of active carbon and remove substances, such as free } \mathrm{Cl} \text {, } \\
\text { chloramine, and organic matter in raw water, that is difficult to remove by RO membrane } \\
\text { Installed as a pretreatment system of RO unit like the softener. }\end{array}$ \\
\hline $\begin{array}{l}\text { Check Filter } \\
\text { (Secondary Filter) }\end{array}$ & $\begin{array}{l}\text { Pore size: } 1 \text { to } 10 \mu \mathrm{m} \text {. Shape: Spool or laminated type filter. Removes tiny particles, such } \\
\text { as abrasion powder and pulverized powder, which could not capture within the } \\
\text { pretreatment systems. Used to protect RO membrane. }\end{array}$ \\
\hline $\begin{array}{l}\text { Reverse Osmosis (RO) } \\
\text { Unit }\end{array}$ & $\begin{array}{l}\text { Utilizing a principle of reverse osmosis, pressure more than the osmotic pressure between } \\
\text { two solutions separated by the RO membrane which is a hardly penetrated } \\
\text { semipermeable membrane except water is applied, and high-purity water is prepared. }\end{array}$ \\
\hline RO Tank & $\begin{array}{l}\text { Installed for buffer of percolating water. UV radiation germicidal light is installed in the } \\
\text { tank to control bacterial contamination of percolating water. }\end{array}$ \\
\hline $\begin{array}{l}\text { Powdered Dialysis } \\
\text { Agent Dissolving } \\
\text { System }\end{array}$ & $\begin{array}{l}\text { Dialysis fluid concentrate: liquid type and powder type. Using a powdered preparation, } \\
\text { the apparatus which dissolves the powder with RO treated water is installed (for } \\
\text { Concentrate A and B). Using a liquid type, a stock-solution storage tank is installed. }\end{array}$ \\
\hline $\begin{array}{l}\text { Central Dialysis Fluid } \\
\text { Delivery System }\end{array}$ & $\begin{array}{l}\text { Apparatus which mixes dilute water (RO treated water) with dialysis fluid concentrate to } \\
\text { produce the dialysis fluid of same composition, and supply the dialysis fluid to patient } \\
\text { bedside monitoring systems. }\end{array}$ \\
\hline $\begin{array}{l}\text { Console Dialysis Unit } \\
\text { (Patient Bedside } \\
\text { Monitoring System) }\end{array}$ & $\begin{array}{l}\text { Apparatus for leading patient's blood into a dialyzer through a blood circuit, supplying } \\
\text { dialysis fluid to a dialyzer, removing solutes by diffusion and excessive water by } \\
\text { ultrafiltration from blood through a semipermeable membrane. Monitors the water } \\
\text { removal, inner pressure of blood circuit, and dialysis fluid concentration. }\end{array}$ \\
\hline
\end{tabular}

3 months to improve the accuracy of measurements.

Next, to evaluate changes in the basic performance of the ETRFs, each ETRF was detached after $1,3,6$, or 12 months of installation to measure its water permeability, ET-retentive capacity, and hollow-fiber membrane intensity. The $\mathrm{RO}$ water at $37^{\circ} \mathrm{C}$ was used to evaluate water permeability performance, and the ultrafiltration rate (UFR) at a net filtration rate (QF) of $500 \mathrm{~mL}$ / minute was measured with the s- $\mathrm{t}-\mathrm{o}-\mathrm{p}$ - $\operatorname{method}^{19}$. A test fluid with a high ET concentration $\left(10^{7}\right.$ to $10^{8}$ $\mathrm{EU} / \mathrm{mL}$ ) (standard ET: Escherichia coli 0111: B4; Difco Laboratories, Detroit, MI, USA) was prepared, and $10 \mathrm{~L}$ of the fluid was passed through the ETRF at $500 \mathrm{~mL} /$ minute, after which the ET concentration at the ETRF exit site was measured. Therefore, the ET-retentive capacity of the ETRF was evaluated by calculating the ratio (retentive ratio) of the ET concentration of the test fluid to that of the fluid obtained at the ETRF exit site.

The strength of hollow fibers obtained from each
ETRF was evaluated by measuring the breaking strength and the breaking elongation with a tensile testing machine (Tensilon universal material testing machine; A\&D Co., Ltd., Tokyo). The breaking strength in a tensile test is the tensile load/force, in kilogram force $(\mathrm{kgf})$, required to fracture the test sample. The breaking elongation in a tensile test is the degree of elongation, expressed as a percentage of the sample's original length, at which the test sample fractures.

The hollow-fiber membrane surfaces of the evaluated ETRFs and the second ETRFs were observed with a scanning electron microscope (SEM) (JMS-6360LA; JEOL Ltd., Tokyo), and elements of the adherent substances were identified with energy dispersive X-ray spectrometry (EDS).

\section{Results}

The upstream water quality in each facility is shown in Table 3. The RO membranes in facility A 
Importance of ETRF in Haemodialysis

Table 3 Upstream water quality data for each facility

\begin{tabular}{lcccc}
\hline Item & Sampling site & $\begin{array}{c}\text { Facility A } \\
\text { (at the point of installation: } \\
\text { before RO membrane renewal) }\end{array}$ & $\begin{array}{c}\text { Facility A } \\
\text { (after RO } \\
\text { membrane renewal) }\end{array}$ & Facility B \\
\hline ET value & Raw water & 15.300 & $7.1969 \pm 2.2545$ & $7.8399 \pm 3.2541$ \\
{$[\mathrm{EU} / \mathrm{mL}]$} & RO water & 0.0119 & $0.0010 \pm 0.0001$ & $0.0224 \pm 0.0171$ \\
\hline Viable cell & Raw water & 0.0074 & $0.0011 \pm 0.0003$ & $0.0049 \pm 0.0025$ \\
count & RO water & 1.3 & $1.5 \pm 0.6$ & $1.4 \pm 0.6$ \\
{$[\mathrm{CFU} / \mathrm{mL}]$} & CDDS exit site & 0.2 & $0.0 \pm 0.0$ & More than 10.0 \\
\hline
\end{tabular}

mean $\pm \mathrm{SD}$

a) ET value transit of pre-ETRF site
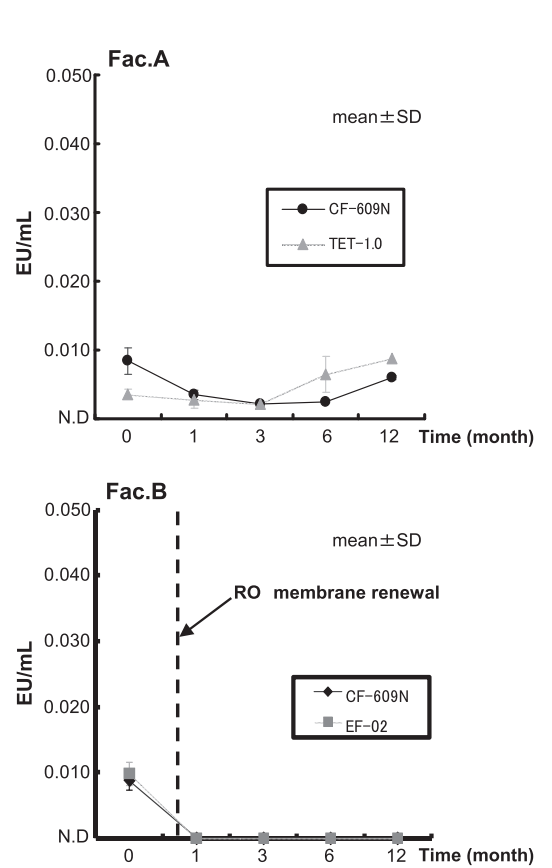

b) Results of viable cell culture with MF method
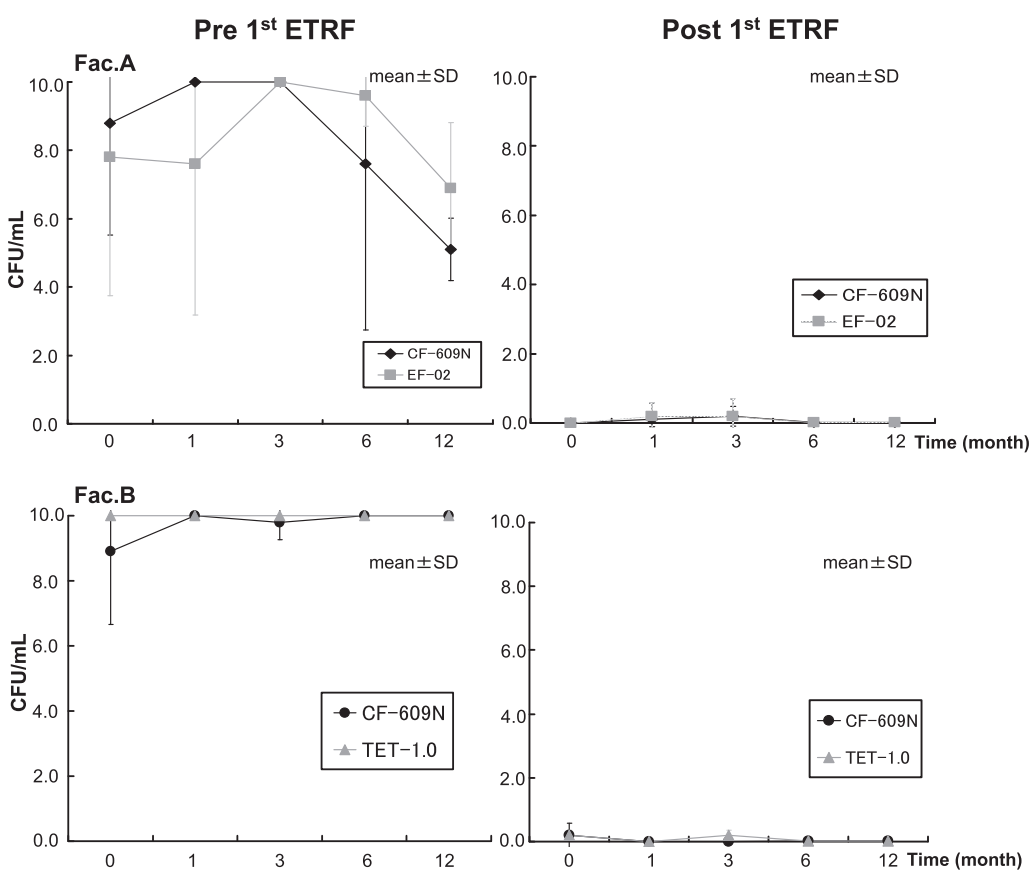

Note) All ET values were less than the limit of detection and viable cell counts were less than $0.1 \mathrm{CFU} / \mathrm{mL}$ at postETRF sites in both facilities.

Fig. 3 The ET values and viable cell counts transition at the terminal sites

were renewed 1 month after the start of the study, after which the ET concentrations of the fluid treated with the RO unit decreased to less than the limit of detection. In facility A the ET concentrations at the terminal site, even at the ETRF entry site, became less than the limit of detection after the RO membrane was renewed, and the ET concentrations in facility $\mathrm{B}$ remained less than $0.01 \mathrm{EU} / \mathrm{mL}$, so that the desired level was consistently achieved (Fig. 3a). In addition, the ET values were less than the limit of detection at post-ETRF points of use in both facilities.

Viable cell counts determined with the membrane filter method (Fig. 3b) in both facilities were less than $0.1 \mathrm{CFU} / \mathrm{mL}$ at post-ETRF sites and were approximately $10 \mathrm{CFU} / \mathrm{mL}$ at pre-ETRF sites.

Basic performance tests showed that UFRs decreased for the EF-02 and CF-609N ETRFs but increased for the TET-1.0 ETRF (Fig. 4). The measurements of ET-retentive ratios showed that an ET-retentive rate of less than $10^{-3}$ (that meant the logarithm reduction value (LRV) was at least 3 : the desirable LRV of ETRFs is 3 or more for ET) was maintained for all ETRFs during the 12-month study period (Table 4). After 12 months, the degree of leakage was greater for the TET-1.0 ETRF than for the other ETRFs, but high retentive ratios were maintained for all 3 ETRFs. 


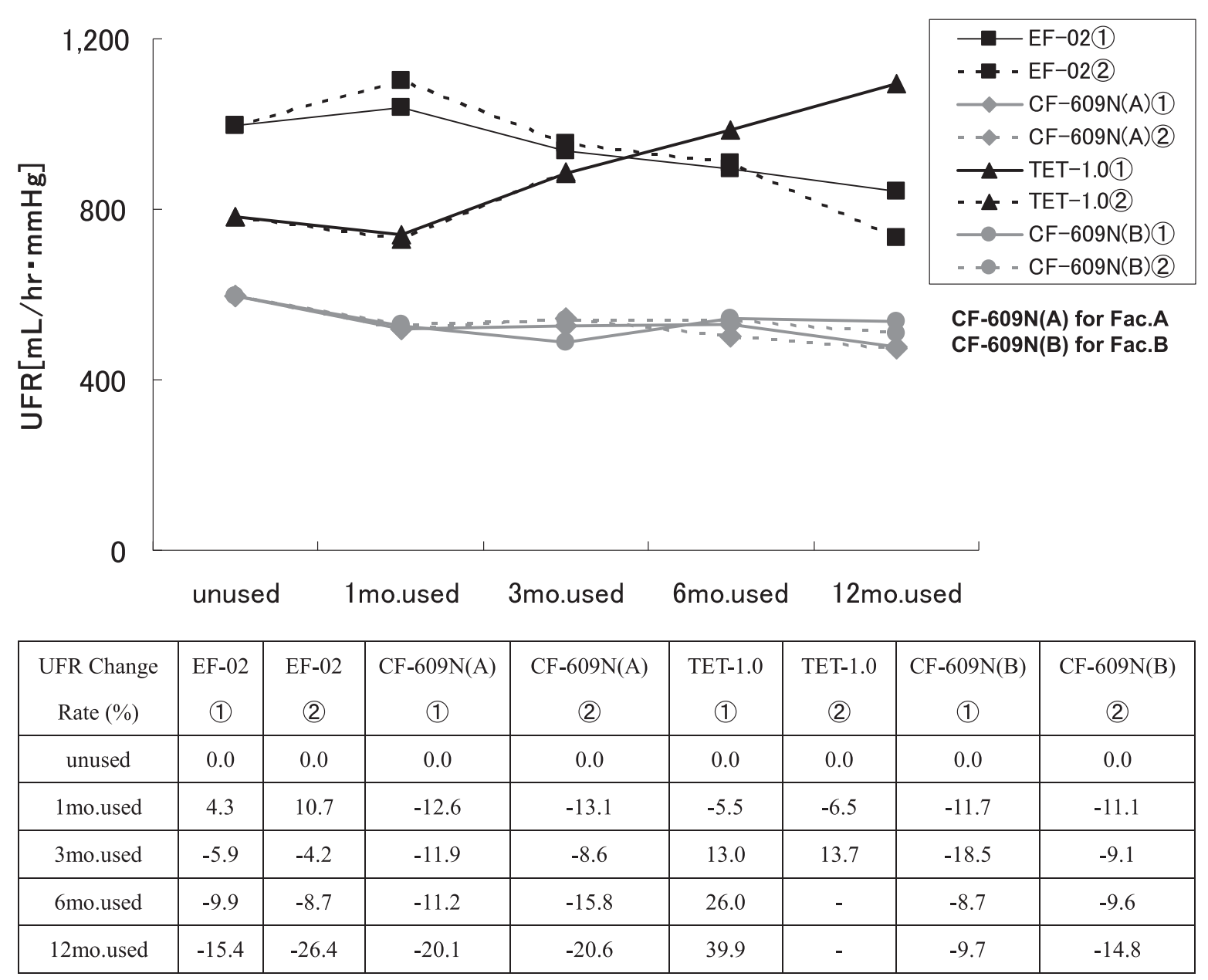

Fig. 4 The UFR values of the ETRFs

Table 4 Changes in ET retentive rate

\begin{tabular}{|c|c|c|c|c|c|c|}
\hline \multirow[b]{2}{*}{ Facility A } & \multicolumn{3}{|c|}{ EF-02 } & \multicolumn{3}{|c|}{ CF-609N (A: with flushing) } \\
\hline & $\begin{array}{c}\text { Entrance conc. } \\
{[\mathrm{EU} / \mathrm{mL}]}\end{array}$ & $\begin{array}{l}\text { Exit conc. } \\
{[\mathrm{EU} / \mathrm{mL}]}\end{array}$ & $\begin{array}{l}\text { Retentive } \\
\text { rate }\end{array}$ & $\begin{array}{c}\text { Entrance conc. } \\
{[\mathrm{EU} / \mathrm{mL}]}\end{array}$ & $\begin{array}{l}\text { Exit conc. } \\
{[\mathrm{EU} / \mathrm{mL}]}\end{array}$ & $\begin{array}{l}\text { Retentive } \\
\text { rate }\end{array}$ \\
\hline unused & $27,690,000$ & $<0.001$ & $3.6 \times 10^{-5}$ & $22,480,000$ & $<0.001$ & $4.4 \times 10^{-5}$ \\
\hline 1 mo. used & $11,586,000$ & $<0.001$ & $8.6 \times 10^{-5}$ & $166,100,000$ & $<0.001$ & $6.0 \times 10^{-6}$ \\
\hline 3 mo. used & $428,200,000$ & $<0.001$ & $2.3 \times 10^{-6}$ & $335,100,000$ & $<0.001$ & $3.0 \times 10^{-6}$ \\
\hline 6 mo. used & $146,100,000$ & $<0.001$ & $6.8 \times 10^{-6}$ & $146,100,000$ & $<0.001$ & $6.8 \times 10^{-6}$ \\
\hline 12 mo. used & $333,900,000$ & 0.0019 & $5.7 \times 10^{-6}$ & $359,400,000$ & $<0.001$ & $2.8 \times 10^{-6}$ \\
\hline \multirow[b]{2}{*}{ Facility B } & \multicolumn{3}{|c|}{ TET-1.0 } & \multicolumn{3}{|c|}{ CF-609N (B: without flushing) } \\
\hline & $\begin{array}{c}\text { Entrance conc. } \\
{[\mathrm{EU} / \mathrm{mL}]}\end{array}$ & $\begin{array}{l}\text { Exit conc. } \\
{[\mathrm{EU} / \mathrm{mL}]}\end{array}$ & $\begin{array}{l}\text { Retentive } \\
\text { rate }\end{array}$ & $\begin{array}{c}\text { Entrance conc. } \\
{[\mathrm{EU} / \mathrm{mL}]}\end{array}$ & $\begin{array}{l}\text { Exit conc. } \\
{[\mathrm{EU} / \mathrm{mL}]}\end{array}$ & $\begin{array}{l}\text { Retentive } \\
\text { rate }\end{array}$ \\
\hline unused & $29,230,000$ & $<0.001$ & $3.4 \times 10^{-5}$ & $22,480,000$ & $<0.001$ & $4.4 \times 10^{-5}$ \\
\hline 1 mo. used & $248,600,000$ & 0.0052 & $2.1 \times 10^{-5}$ & $166,100,000$ & $<0.001$ & $6.0 \times 10^{-6}$ \\
\hline 3 mo. used & $428,200,000$ & $<0.001$ & $2.3 \times 10^{-6}$ & $11,586,000$ & $<0.001$ & $8.6 \times 10^{-5}$ \\
\hline 6 mo. used & $124,900,000$ & 0.0090 & $7.2 \times 10^{-5}$ & $163,100,000$ & $<0.001$ & $6.1 \times 10^{-6}$ \\
\hline 12 mo. used & $453,500,000$ & 0.0494 & $1.1 \times 10^{-4}$ & $359,400,000$ & 0.0022 & $6.1 \times 10^{-6}$ \\
\hline
\end{tabular}

ET retentive rate less than $10^{-3}$ (LRV3) was maintained for all ETRFs

Measurements of hollow-fiber membrane intensity are shown in Figure 5. The breaking intensity was higher for the CF-609N ETRF, which has a thicker membrane. Degenerative changes over time were found in the TET-1.0 ETRF, but only minor changes were found in the other 2 ETRFs. The breaking 
[ Breaking Strength ]
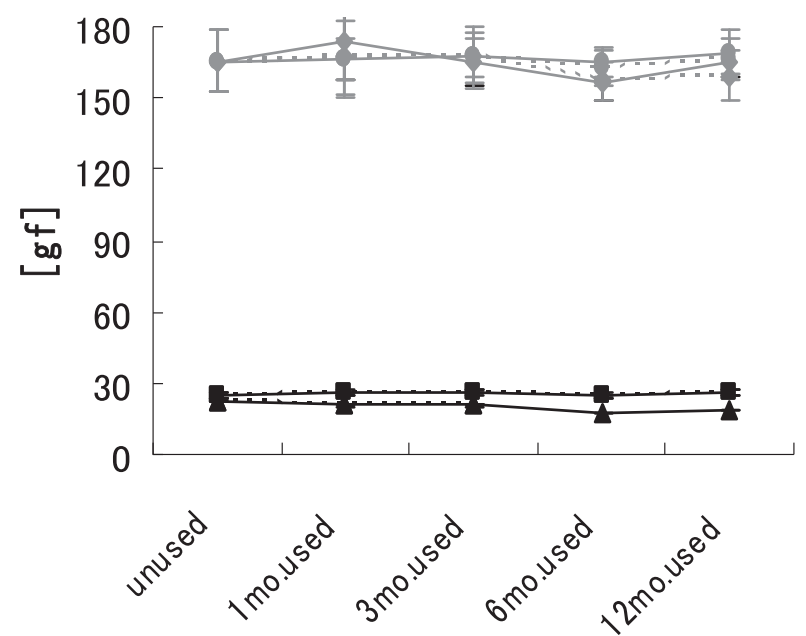

[ Breaking Elongation ]
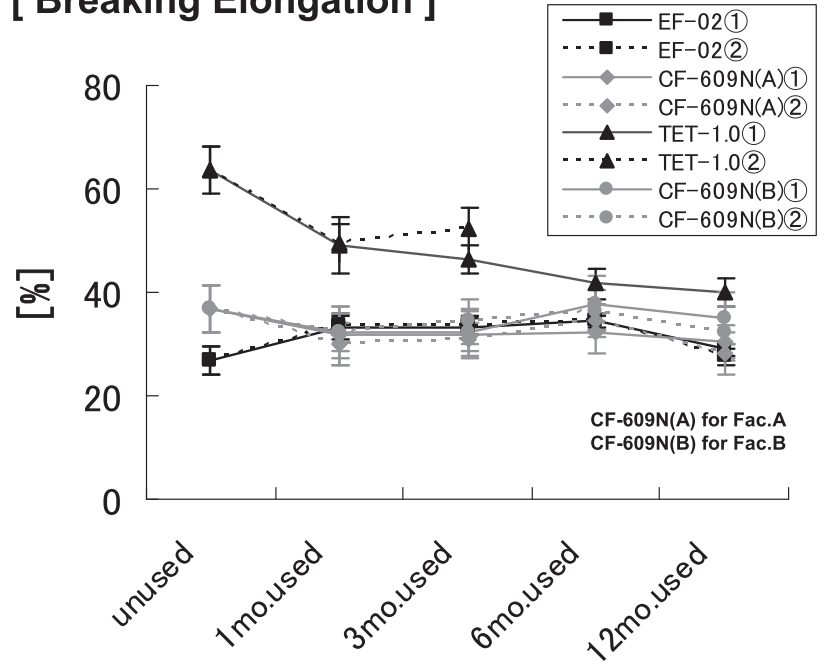

\begin{tabular}{|c|c|c|c|c|c|c|c|c|}
\hline $\begin{array}{c}\text { Breaking } \\
\text { Strength }\end{array}$ & EF-02 & EF-02 & CF-609N(A) & CF-609N(A) & TET-1.0 & TET-1.0 & CF-609N(B) & CF-609N(B) \\
\hline unused & 0.0 & 0.0 & 0.0 & 0.0 & 0.0 & 0.0 & 0.0 & 0.0 \\
\hline 1mo.used & 5.2 & 4.0 & 4.9 & 1.4 & -8.4 & -7.4 & 0.5 & 0.4 \\
\hline 3mo.used & 6.4 & 4.8 & -0.3 & 1.2 & -9.9 & -8.3 & 1.0 & 0.9 \\
\hline 6mo.used & -0.4 & 0.0 & -5.3 & -5.0 & -22.5 & - & -0.2 & -1.8 \\
\hline 12mo.used & 5.2 & 5.2 & -0.6 & -3.6 & -16.7 & - & 2.1 & 0.6 \\
\hline Breaking & EF-02 & EF-02 & CF-609N(A) & CF-609N(A) & TET-1.0 & TET-1.0 & CF-609N(B) & CF-609N(B) \\
\hline Elongation & 1 & 2 & -1 & 2 & -1 & 2 & $(1)$ & 2 \\
\hline unused & 0.0 & 0.0 & 0.0 & 0.0 & 0.0 & 0.0 & 0.0 & 0.0 \\
\hline 1mo.used & 24.3 & 24.8 & -14.5 & -19.1 & -22.8 & -22.0 & -12.5 & -12.6 \\
\hline 3mo.used & 24.3 & 24.9 & -13.5 & -15.9 & -27.3 & -18.1 & -11.9 & -6.9 \\
\hline 6mo.used & 28.4 & 28.7 & -12.7 & -6.2 & -34.7 & - & 2.4 & -1.9 \\
\hline 12mo.used & 8.2 & 3.0 & -17.9 & -23.3 & -37.4 & - & -5.4 & -13.0 \\
\hline
\end{tabular}

Fig. 5 The strength of hollow fibers evaluation

elongation decreased for the $\mathrm{CF}-609 \mathrm{~N}$ and decreased to an even greater extent for the TET-1.0.

The SEM examination of the surfaces ETRF hollow-fiber membranes showed a greater amount of adherent substances on the CF-609N membrane with the duration of use than on the EF-02 or TET1.0 membranes, even though only a limited area of the surface was examined. The chemical composition, determined with EDS, of substances adherent to hollow-fiber surfaces included $\mathrm{F}, \mathrm{Al}, \mathrm{Si}$, $\mathrm{Cl}, \mathrm{K}, \mathrm{Ca}$, Ti, Cr, Fe, and $\mathrm{Nb}$, along with $\mathrm{C}, \mathrm{O}$, and $\mathrm{S}$, which were considered to be derived from the hollow-fiber materials. These elements were found in significantly greater amounts on CF-609N membranes. All elements detected with EDS were present in the water/agent used for preparing the dialysis fluid or in the fluid path of the dialysis system. Only elements derived from the hollow fibers and the dialysis fluid were found in substances adhering to the hollow fibers of the second ETRF.

\section{Discussion}

Aquatic microbes, including Gram-negative 
bacteria, Gram-positive bacteria, and fungi, are isolated when the dialysis water and fluid are cultured on an oligotrophic medium. Because ETs are isolated from the outer membranes of Gramnegative bacteria, the presence of Gram-positive bacteria or fungi does not affect the ET concentration. That is, the ET concentration and the viable cell count do not always correlate; therefore, both the ET concentration and the viable cell count must be controlled ${ }^{12}$. This mechanism might explain the data shown in Table 3 why the some viable cell counts between facilities A and B differed despite there being no difference in the ET concentrations.

Japanese standards for ET concentrations in dialysis fluid water have been strict, but standards for viable cell count have been less clear. However, in line with the International Organization for Standardization, which emphasizes viable cell counts, Japanese scientific societies began to specify standards for viable cell counts in their guidelines ${ }^{14,15}$.

In facility $\mathrm{B}$, a conventional water-treatment system was installed 10 years ago. With such a conventional system, bacteria can proliferate because antimicrobial measures are insufficient without a system, such as a recirculation line, to prevent RO water stagnation. Furthermore, the RO fluid path contains structural dead space that cannot be reached by a disinfective drug solution; should a contaminating nest develop in the dead space and form a biofilm, eliminating it would be difficult ${ }^{12,20}$. On the other hand, soon after facility A was opened, a novel water treatment system, which includes a recirculation system and a hot-water disinfection mechanism to prevent bacterial contamination, was introduced. The recirculation system from the RO tank to the RO membrane ensures that even if the $\mathrm{RO}$ tank is filled with water and $\mathrm{RO}$ water production is stopped, stagnation is prevented by pumping the RO water through a loop circuit. Through thermal conductivity, the hot water disinfects the dead space, where a disinfective drug solution cannot reach, thereby killing bacteria and controlling biofilm formation ${ }^{20}$. Moreover, the hotwater disinfection process is performed automatically, by the push of a button, unlike the drug-solution disinfection process of a conventional system, which is performed manually. Therefore, disinfection is simpler and can be performed more frequently.

Although ET concentrations increased and leakage of the $\mathrm{RO}$ membrane was suspected in facility $A$ at the start of this evaluation period, we believe that the leakage of microbes was not found because the microbes were much larger than the ETs. Despite the leakage of ETs into the RO water having been detected, viable cell counts were not increased, possibly because of the $\mathrm{RO}$ recirculation system and periodic hot-water disinfection.

The evaluation of water quality showed that the ET concentrations were less than the limit of detection for samples obtained at post-ETRF sites. The viable cell counts at pre-ETRF sites were approximately $10 \mathrm{CFU} / \mathrm{mL}$. For samples obtained at post-ETRF sites, cell counts ranged from 0.1 to 0.5 $\mathrm{CFU} / \mathrm{mL}$ from the start of the study until 3 months later, possibly because of contamination through handling of the device used for the membrane filter method. After 6 months, when the procedure was reviewed and improved, colonies were not formed, even though the filtrate volume had been increased from $10 \mathrm{~mL}$ to $100 \mathrm{~mL}$. Tests of the basic performance of ETRFs found that UFRs decreased for the EF-02 and CF-609N ETRFs but increased for the TET-1.0. The EF-02 and CF-609N ETRFs have a hydrophobic membrane, which is believed to absorb ETs via hydrophobic bonding ${ }^{18}$. Clogging of the membrane because of the absorption or capture of suspended ETs, silicon, and other substances might have decreased UFRs. In contrast, the TET-1.0 ETRF has a membrane to which polyvinylpyrrolidone (PVP) has been added to make it hydrophilic. Because the disinfective hypochlorous acid can dissolve $\mathrm{PVP}^{21}$, a possible reason the UFR of the TET-1.0 increased is that the pores of the membrane might have enlarged because the PVP was dissolved through repeated washing and disinfection with long-term use. Evaluation of the ET-retentive ratio showed that of the degree of leakage was greater with the TET-1.0 than with the other 2 ETRFs after 12 months; however, the LRV was greater than 3 for all 3 ETRFs. Evaluation of the hollow-fiber intensity showed degenerative 
changes over time in the TET-1.0 and CF-609N ETRFs. In particular, the breaking intensity and breaking elongation were significantly decreased in TET-1.0; therefore, the effects of the PVP dislodgement were considered. The substances adherent to hollow fibers included silicon from the powdered dialysis agent, iron from the fluid path, and elements derived from stainless steel, and greater amounts of such substances were found on the CF-609N ETRF. Examination with an SEM showed no substances, except the hollow fiber and elements derived from the dialysis fluid, adhering to the hollow fibers of the second ETRFs.

\section{Conclusions}

Viable cells were found at the terminal site, even when the ET concentration was less than the limit of detection. The strict management of water quality at the upstream side is as important as it has ever been; however, ETRF installation is useful for achieving and maintaining the quality standards for ultrapure dialysis fluid. Furthermore, our results suggest that ETRF installation helps prevent the entry to the patient's blood of ETs, viable cells, and such substances as silicon and metals.

\section{References}

1. Cappelli G, Ricardi M, Bonucchi D, De Amicis: Quality of water, dialysate and infusate. Contrib Nephrol 2007; 158: 80-86.

2. Ledebo I: Ultrapure dialysis fluid-direct and indirect benefits in dialysis therapy. Blood Purif 2004; 22 (suppl 2): 20-25.

3. Arizono K, Nomura K, Motoyama T, et al.: Use of ultrapure dialysate in reduction of chronic inflammation during hemodialysis. Blood Purif 2004; 22 (suppl 2): 26-29.

4. Uchino J, Kawasaki T: Purification of dialysis water in the central dialysis fluid delivery system in Japan: a prospective observation study. Blood Purif 2009; 27 (suppl 1): 64-69.

5. Ando M: The water treatment machine (3-1) and endotoxin retentive filter (4). In The Guidebook for Blood Purification Machine Maintenance (Clin Eng sep vol) (The Japanese Society for Therapeutics and Engineering, ed), 2006; pp 51-53, Shujunsha, Tokyo [in Japanese].

6. Hisano $\mathrm{T}$ : The chronic toxicity of low concentration endotoxin. In The Haemodialysis and Endotoxin (Takezawa S, ed), 2002; pp 35-45, Tokyo Igakusha, Tokyo [in Japanese].

7. Mineshima M: The possibility of endotoxin penetration with reverse filtration. In The Haemodialysis and Endotoxin (Takezawa S, ed), 2002; pp 65-71, Tokyo Igakusha, Tokyo [in Japanese].

8. Yamashita A: The possibility of endotoxin penetration with diffusion. In The Haemodialysis and Endotoxin (Takezawa S, ed), 2002; pp 73-84, Tokyo Igakusha, Tokyo [in Japanese].

9. Isakozawa Y: The endotoxin permeation of dialyzermembrane. In The Haemodialysis and Endotoxin (Takezawa S, ed), 2002; pp 89-90, Tokyo Igakusha, Tokyo [in Japanese].

10. Tsuchida K, Nakamura M, Yoshikawa K, Minakuchi J, Takesawa S: Current situation of endotoxin retentive filter. Blood Purif 2009; 27 (suppl 1): 28-35.

11. Nakamura F, Urano T, Mashita H, et al.: 3-1 Water treatment device. Clin Eng 2006; (sep vol): 42-53.

12. Iwamoto $\mathrm{H}$, Koga $\mathrm{N}$ : The dialysis fluid purification theory. Nippon Rinsho 2004; 62 (ex 5): 121-125.

13. Tsuchida K: The basics of endotoxin. In the HDF Therapy Handbook (The Japanese Society for Hemodiafiltration, ed), 2000; pp 34-45, Nankodo, Tokyo [in Japanese].

14. Kawanishi H, Akiba T, Masakane I, et al.: Standard on microbiological management of fluids for hemodialysis and related therapies by the Japanese Society for Dialysis Therapy 2008. Ther Apher Dial 2009; 13: 161-166.

15. Kawanishi $\mathrm{H}$ : The current situation of dialysis fluid purification policy in Japan: trying to establish a system for microbes detection. Kidney and Dial 2005; 59 (High Performance Membrane 05): 12-16. [in Japanese].

16. Numata S, Makio K, Muro S, et al.: The deterioration of endotoxin cut filter in long-term use. Kidney and Dial 2008; 65 (High performance Membrane '08): 8689. [in Japanese].

17. The guideline of water quality management for dialysis fluid. (The Japanese Society for Hemodiafiltration, ed), 1996; pp 46-52, The Japanese Society for Hemodiafiltration, Kobe [in Japanese].

18. Hoshino T, Shibamoto $\mathrm{T}$ : The good usage of endotoxin cut filter. Clin Eng 2008; 19: 879-885.

19. Ota $\mathrm{K}$ : The dialyzer performance evaluation standard (The Japanese Society for Artificial Organs, ed), 1982; pp 7-9. The Japanese Society for Artificial Organs, Tokyo [in Japanese].

20. Matsuo K, Matsuyama R, Nakamoto M: The biofilm control with hydrothermal sterilization. Clin Dial 2007; 23: 613-620.

21. Okadome T, Takezawa S, Itagaki M, Takeuchi T: The time-dependent deterioration of endotoxin cut filter (ETCF) performance. Kidney and Dial 2002; 53 (HDF Therapy '02): 112-114.

(Received, April 7, 2010)

(Accepted, December 29, 2010) 